\title{
EFFICACY AND SAFETY OF THROMBOPOIETIN RECEPTOR AGONISTS IN MODERN TREATMENT OF IMMUNE THROMBOCYTOPENIA
}

\author{
ANDRADA PARVU ${ }^{1,2 *}$, OLGA HILDA ORASAN ${ }^{3}$, STEFAN VLAD POP $^{1,4}$, IULIA ANDREA $^{2}$ \\ ZSOLDOS $^{1}$, CRISTINA CATANA ${ }^{1}$, IOANA STEFANIA DEAC ${ }^{1}$, ANCA SIMONA BOJAN ${ }^{1,2}$ \\ ${ }^{1}$ Haematology Department, "Iuliu Hațieganu” University of Medicine and Pharmacy, 73 21-Decembrie Boulevard, Cluj- \\ Napoca, Romania \\ ${ }^{2}$ Haematology Department, "Prof. Dr. Ion Chiricuţă" Oncological Institute, 73 21-Decembrie Boulevard, Cluj-Napoca, \\ Romania \\ ${ }^{3} 4^{\text {th }}$ Medical Department, "Iuliu Hațieganu” University of Medicine and Pharmacy, 18 Republicii Street, Cluj-Napoca, \\ Romania \\ ${ }^{4}$ Emergency County Hospital, 2 Ravensburg Street, Satu-Mare, Romania
}

*corresponding author: parvuandrada@hotmail.com

Manuscript received: June 2020

\begin{abstract}
Immune thrombocytopenia (IT), characterized by isolated platelet decrease and bleeding, could be primary or secondary to infections, autoimmune diseases, drugs. Classical treatments for IT are corticosteroids, immunoglobulins $\left(1^{\text {st }}\right.$ line $)$ and splenectomy, immunosuppression $\left(2^{\text {nd }}\right.$ line), therapies based on decreasing platelets' destruction. Thrombopoietin receptor agonists (TRA), romiplostim, eltrombopag and avatrombopag, modern drugs used for refractory patients, increase platelets production. The aim of the article is a review of literature based on 59 scientific articles regarding the efficacy and safety of TRA in primary IT. This review is helpful to specialists, given the limited experience with these drugs, approved in 2008 in the United States and in 2009 in Europe. TRA have shown good efficacy, treatment leading to increased platelet counts, decreased haemorrhagic episodes, reduced concomitant medication. TRA were well tolerated, the adverse effects reported were medullary fibrosis, thrombosis, headache, rhinopharyngitis, hepatocitolysis, fatigue.
\end{abstract}

\section{Rezumat}

Trombocitopenia imună (TI), caracterizată prin scăderea numărului de trombocite şi hemoragii, poate fi primară sau secundară unor infecţii, boli autoimune, medicamente. Tratamentele clasice scad distrucţia trombocitelor şi sunt reprezentate de corticoizi şi imunoglobuline (linia I), splenectomie şi imunosupresie (linia II). Agoniştii receptorilor de trombopoietină (ART), romiplostin, eltrombopag și avatrombopag, medicamente moderne destinate cazurilor refractare, stimulează trombocitopoieza. Acestă analiză sistematică de literatură se bazează pe 59 articole de specialitate şi analizează eficacitatea şi siguranţa ART în TI primară. Lucrarea este utilă având în vedere experienţa limitată cu aceste medicamente aprobate în 2008 în Statele Unite şi în 2009 în Europa. ART au dovedit o bună eficienţă, crescând numărul de trombocite, scăzând numărul şi amploarea episoadelor hemoragice, reducând medicaţia concomitentă. ART sunt bine tolerate, efectele adverse constând în mielofibroză, tromboze, cefalee, rinofaringită, hepatocitoliză, fatigabilitate.

Keywords: thrombopoietin receptor agonists, immune thrombocytopenia

\section{Introduction}

Immune thrombocytopenia (IT) is an autoimmune disease characterized by isolated thrombocytopenia (platelet count under $100.000 / \mu \mathrm{L}$ ) in the absence of other causes or disorders that may be associated with thrombocytopenia. The dominant clinical manifestation is bleeding, which generally correlates with the severity of thrombocytopenia $[7,18,19,58]$.

According to the classical pathogenetic theory, immune thrombocytopenia is mediated by autoantibodies, platelet antibodies that accelerate platelet destruction and inhibit their production. New pathogenetic theories are based on multiple immune mechanisms of platelet and their progenitors' destruction (complement mediated cytotoxicity of $\mathrm{T}$ lymphocytes and $\mathrm{CD} 4^{+}$mediated cytotoxicity). Another modern idea is that platelet production is variably impaired, antibodies could contribute to megakaryocyte destruction, induce apoptosis, impede platelet release, or promote intramedullary phagocytosis $[7,18]$.

The disease could be primary (idiopathic) or secondary to infections (eg. Helicobacter pylori, B or C hepatitis, HIV), to other autoimmune diseases (systemic erythematous lupus, rheumatoid arthritis or other collagenous pathologies) or to certain drugs. In addition, environmental and genetic factors may impact 
platelet turnover, propensity to bleed, and response to IT directed therapy [7, 18].

The International Working Group (IWG) for studying IT also defines this disease as newly diagnosed (diagnosis to 3 months), persistent (3 to 12 months from diagnosis) or chronic (lasting for more than 12 months) [58].

Classical concept of treating this disease was to stop peripheral clearance of the platelets (using corticosteroids, splenectomy and other immunosuppressors). After elaborating the new pathogenetic concept described before, new drugs were introduced, as thrombopoietin receptor agonists (TRA).

\section{Materials and Methods}

The objective of this literature review is to perform a systematic review of current evidence on the efficacy and safety of thrombopoietin receptor agonists in primary immune thrombocytopenia.

The inclusion criteria of the studies in this review were: primary studies; studies published in English language; the possibility of accessing the entire article for free; studies focused on the safety and efficacy of treatment with TRA in primary immune thrombocytopenia.

The exclusion criteria of the studies were: studies approaching treatment with TRA, but not its efficacy and safety; studies on pediatric patients; studies based on secondary immune thrombocytopenia patients; studies based on other types of thrombocytopenia (non-immune, drug, congenital, etc.)

Study searches were conducted in the Medline and Cochrane Central Register of Controlled Trials (CENTRAL) databases with the "free full text" option enabled.

In the Medline database keywords used were: (thrombopoietin mimetic AND) (thrombopoietin receptor agonists AND) (thrombopoietin receptor thrombocytopenia) OR (eltrombopag AND (thrombocytopenic OR thrombocytopenia) OR thrombocytopenia)) OR (romiplostim AND (thrombocytopenic OR thrombocytopenia)) OR (avatrombopag AND (thrombocytopenic OR thrombocytopenia)).

These searches resulted in 237 articles and an erratum of an article. From the manual search of the key articles in the bibliography, there were no other relevant articles that were not already included in the analysis that met the inclusion criteria.

Following the analysis of the studies, 178 articles were excluded, the ones that did not meet the inclusion criteria or had exclusion criteria. The number of studies included in the analysis was 59 and the erratum.

The data was extracted from the articles in a uniform and impartial manner using an electronic data collection file that included: eligibility criteria, year of appearance, study design, population included, number of included patients, intervention, outcome of treatment and treatment safety, including adverse reactions.

The data of the 59 papers included in the systematic analysis were analysed following the intended effects: the efficacy of treatment with analogues of TRA and the short- and long-term safety of the treatment. In these studies, 2 studies approached all three drugs, 16 studies approached eltrombopag and romiplostim, 11 studies approached eltrombopag only, 23 studies approached romiplostim and 7 studies approached avatrombopag.

\section{Results and Discussion}

\section{Current guidelines for IT medication}

Regarding to IWG, first line of treatment consists in corticosteroids (as immunosuppressors) or high dose immunoglobulins (reticuloendothelial system blockade) and second line treatments are represented by splenectomy (removing the site of platelets' destruction), rituximab (anti CD 20 monoclonal antibody which targets and destroys $\mathrm{CD} 20^{+} \mathrm{B}$ lymphocytes which are presumably involved in autoantibody production), thrombopoietin receptor agonists (which increase platelets production), fostamatinib (Syk inhibitor, which inhibits platelet's phagocytosis by splenic macrophages due to inhibition of cytoskeleton), other immunosuppressors (azathioprine, cyclophosphamide), Vinca alkaloids (spleen macrophage blockade). Immune thrombocytopenia treatment is very well specified in international guidelines based on pharmaceutical good practice $[7,18,19,24,25$, 48, 78].

TRA are new and promising second generation drugs. Firstly, there were produced and administrated recombinant human thrombopoietin analogues. These drugs were abandoned because of the development of cross-reactive antibodies against endogenous thrombopoietin which produced sustained thrombocytopenia. This is the reason for producing secondgeneration thrombopoietin receptor agonists that have no sequence homology to endogenous thrombopoietin. These drugs are romiplostim, eltrombopag and the newest avatrombopag, which proved efficacy even in patients suffering refractory disease $[7,22,25,26$, $30,58,83]$. In 2008 romiplostim, and eltrombopag were approved by US Food and Drug Administration (FDA) and in 2009 by European Medicines Agency (EMA) [85]. In 2018 avatrombopag was approved by FDA [25].

Romiplostim (administered as a once-weekly subcutaneous injection) is a synthetic peptide made of four peptides linked to an IgG Fc fragment. This drug binds thrombopoietin receptor on megakaryocytes at the same location as endogenous thrombopoietin and stimulates megakaryocyte proliferation and platelet production through intracellular Janus kinase/signal transducer and activator of transcription (JAK/STAT) and mitogen-activated protein kinase (MAPK) signalling. 
In a phase III trial, a durable platelet count response (defined as the achievement of a platelet count of $50 \times 10^{9} / \mathrm{L}$ or higher for 6 or more of the last 8 weeks of treatment) was achieved in $50 \%$ of 83 patients receiving Romiplostim compared with one of 42 patients receiving placebo. Weekly doses of Romiplostim range from 1 to $10 \mu \mathrm{g} / \mathrm{kg}$. Weekly doses are titrated up or down, depending on the platelet count response, to maintain the platelet count in the appropriate range $\left(30-100 \times 10^{9} / \mathrm{L}\right)[7,20,26,45$, 58, 83].

Eltrombopag (administered as a $50 \mathrm{mg}$ tablet once daily) is a small molecule, nonpeptide TRA that activates thrombopoietin receptor by binding to its transmembrane domain. In contrast to romiplostim, eltrombopag does not compete with circulating thrombopoietin for binding to thrombopoietin receptor. In a phase III trial, the odds of responding to eltrombopag were approximately eight times higher than with placebo throughout the 6-month treatment period. Durable responses were achieved in $60 \%$ of 95 patients receiving maintenance eltrombopag compared with $10 \%$ of 39 patients receiving placebo. The time to respond similar to Romiplostim, with a minimal need for dose titration. Disadvantage of this drug is that the patient must adhere to dietary restrictions, a four hours restricted window around the dose [7, 22, 23, 58].

Avatrombopag belongs to the second generation of new oral non peptide TRA and was introduced in USA 2018, for the treatment of ITP and chronic liver disease induced thrombocytopenia. Its mechanism of action is similar to Romiplostim, consists in stimulating megakaryocytes proliferation via JAK/ STAT and MAPK signalling. The few studies of avatrombopag showed significantly increased platelet response rate of $67-93 \%$ and decreased concomitant ITP medication used. Initial dose is $20 \mathrm{mg}$ po/day, with possibility to increase at $40 \mathrm{mg}$ po/day, but not to exceed it. There are no dietary restrictions and this may increase patient's compliance.

There are some data proving that romiplostim is approximately eight times more potent than eltrombopag at increasing the platelet count and avatrombopag was approximately 3 times more potent than eltrombopag $[3,21,65,79]$.

Lusutrombopag has been developed, its indication being for periprocedural thrombocytopenia in chronic liver diseases. Maybe in the future this drug will also be used in ITP [ 21, 79].

TRA is generally well tolerated, all three drugs have been statistically associated to development of bone marrow reticulin fibrosis in patients with IT. Myelofibrosis disappeared when the drug was discontinued. TRA has also been associated with thromboembolic events and headache, fatigue and insomnia. Eltrombopag has been associated with serum liver test abnormalities in approximately $10 \%$ of patients. Long-term followup data for patients treated with these agents are limited [7, 20, 22, 23, 26, 45, 58, 83]. A summary of the number of studies analysed for each effect is shown in Table I.

Table I

Characteristics of the studies included in review

\begin{tabular}{|c|c|c|c|c|c|c|}
\hline No. & \begin{tabular}{|c|} 
Design \\
(as author defined it)
\end{tabular} & $\begin{array}{l}\text { Number of } \\
\text { patients }\end{array}$ & Intervention & Follow up & Aim of the study & Reference \\
\hline 1 & $\begin{array}{c}\text { Randomised Phase I } \\
\text { trial, } \\
\text { Placebo controlled }\end{array}$ & 73 healthy subjects & Eltrombopag treatment & 10 days & $\begin{array}{c}\text { Safety, } \\
\text { pharmacokinetics }\end{array}$ & [38] \\
\hline 2 & Retrospective study & 206 subjects & $\begin{array}{l}\text { Thrombopoietin levels } \\
\text { in several pathologies }\end{array}$ & $\begin{array}{c}\text { Not } \\
\text { applicable } \\
\text { (NA) }\end{array}$ & $\begin{array}{c}\text { Thrombopoietin level } \\
\text { predicts response to } \\
\text { TRA }\end{array}$ & [54] \\
\hline 3 & Prospective study & $\begin{array}{l}142 \text { patients with } \\
\text { immune } \\
\text { thrombocytopenia } \\
\text { (IT) }\end{array}$ & $\begin{array}{l}\text { Romiplostim treatment } \\
\text { in chronic IT }\end{array}$ & 3 years & Efficiency and safety & [14] \\
\hline 4 & Retrospective study & 83 IT patients & Romiplostim treatment & NA & $\begin{array}{c}\text { Corelation between } \\
\text { thrombopoietin level } \\
\text { and TRA response }\end{array}$ & [47] \\
\hline 5 & Retrospective study & $\begin{array}{l}30 \text { IT patients, } \\
\text { refractory after } 7 \\
\text { years of treatment }\end{array}$ & $\begin{array}{l}\text { Possibility of stopping } \\
\text { romiplostim treatment }\end{array}$ & 4.5 years & $\begin{array}{c}\text { Remission } \\
\text { maintenance after } \\
\text { stopping romiplostin } \\
\text { treatment }\end{array}$ & [17] \\
\hline 6 & Retrospective study & NA & Romiplostim treatment & NA & $\begin{array}{l}\text { Romiplostim safety } \\
\text { and efficacy }\end{array}$ & [84] \\
\hline 7 & Retrospective study & 125 patients & Romiplostim treatment & 24 weeks & $\begin{array}{c}\text { Immunoglobulins a } \\
\text { therapy after } \\
\text { romiplostim treatment }\end{array}$ & [69] \\
\hline
\end{tabular}


FARMACIA, 2021, Vol. 69, 2

\begin{tabular}{|c|c|c|c|c|c|c|}
\hline No. & $\begin{array}{c}\text { Design } \\
\text { (as author defined it) }\end{array}$ & $\begin{array}{c}\text { Number of } \\
\text { patients }\end{array}$ & Intervention & Follow up & Aim of the study & Reference \\
\hline 8 & $\begin{array}{l}\text { Double blind } \\
\text { randomised trial, } \\
\text { followed up by a } \\
\text { prospective study }\end{array}$ & 23 patients & $\begin{array}{c}\text { Eltrombopag } \\
\text { treatment, Japanese } \\
\text { patients }\end{array}$ & 26 weeks & $\begin{array}{c}\text { Efficacy of TRA in } \\
\text { low doses for Asian } \\
\text { population }\end{array}$ & [82] \\
\hline 9 & Retrospective study & $\begin{array}{c}260 \text { patients } \\
\text { analysed, } 49 \text { TRA } \\
\text { treated }\end{array}$ & Eltrombopag treatment & 6 months & $\begin{array}{c}\text { Complete remission } \\
\text { maintenance after } \\
\text { stopping eltrombopag } \\
\text { treatment }\end{array}$ & [34] \\
\hline 10 & Case series & $\begin{array}{c}9 \text { patients, including } \\
8 \text { splenectomised }\end{array}$ & TRA treatment & NA & $\begin{array}{l}\text { Sustained complete } \\
\text { remission after } \\
\text { treatment }\end{array}$ & [32] \\
\hline 11 & $\begin{array}{l}\text { Retrospective and } \\
\text { prospective study }\end{array}$ & $\begin{array}{l}11 \text { patients with } \\
\text { bone marrow } \\
\text { biopsy, selected } \\
\text { from } 271 \text { patients }\end{array}$ & Romiplostim treatment & NA & Bone marrow fibrosis & [48] \\
\hline 12 & Case report & 1 patient & Romiplostim treatment & NA & $\begin{array}{c}\text { Romiplostim } \\
\text { treatment in case of a } \\
\text { immunosuppressed } \\
\text { patient }\end{array}$ & {$[61]$} \\
\hline 13 & Retrospective study & 494 patients & $\begin{array}{c}\text { Eltrombopag } \\
\text { treatment }\end{array}$ & NA & \begin{tabular}{c|c} 
Haemostasis during \\
eltrombopag treatment
\end{tabular} & [79] \\
\hline 14 & Retrospective study & 115 patients & Romiplostim treatment & 168 weeks & $\begin{array}{c}\text { Bleeding and } \\
\text { thrombosis }\end{array}$ & [31] \\
\hline 15 & Prospective study & $\begin{array}{l}17 \text { IT patients, } 9 \\
\text { healthy subjects }\end{array}$ & TRA treatment & NA & $\begin{array}{c}\text { Improvement of T } \\
\text { lymphocytes activity }\end{array}$ & [9] \\
\hline 16 & $\begin{array}{c}\text { Multicentric } \\
\text { randomized trial }\end{array}$ & 234 patients & IT treatment & 52 weeks & $\begin{array}{l}\text { Romiplostim or } \\
\text { standard of care }\end{array}$ & [49] \\
\hline 17 & Case-control study & \begin{tabular}{|c|}
24 IT patients, 100 \\
healthy subjects
\end{tabular} & IT treatment & NA & $\begin{array}{c}\text { Nonresponders to } \\
\text { eltrombopag }\end{array}$ & [10] \\
\hline 18 & $\begin{array}{l}\text { Observational } \\
\text { multicentric } \\
\text { retrospective trial }\end{array}$ & 72 patients & Romiplostim treatment & 2 years & Safety and efficacy & [42] \\
\hline 19 & Case series & 8 patients & IT treatment & NA & Bone marrow fibrosis & [12] \\
\hline 20 & Case-control study & $\begin{array}{c}20 \text { splenectomised } \\
\text { patients, } 20 \text { healthy } \\
\text { volunteers as a } \\
\text { control group }\end{array}$ & Eltrombopag treatment & 28 days & $\begin{array}{l}\text { Consequences of } \\
\text { eltrombopag on } \\
\text { platelets function }\end{array}$ & {$[68]$} \\
\hline 21 & Case series & 4 patients & $\begin{array}{c}\text { Eltrombopag } \\
\text { treatment }\end{array}$ & 20 months & Avoiding splenectomy & [40] \\
\hline 22 & Case report & 2 patients & $\begin{array}{l}\text { TRA treatment in } \\
\text { refractory IT }\end{array}$ & 2 years & \begin{tabular}{|c|} 
Cross resistance \\
between eltrombopag \\
and romiplostim
\end{tabular} & [75] \\
\hline 23 & $\begin{array}{c}\text { Multicentric } \\
\text { randomized trial }\end{array}$ & 234 patients & Romiplostim treatment & 52 weeks & \begin{tabular}{|c|} 
Romisplostim \\
treatment or standard \\
of care
\end{tabular} & [46] \\
\hline 24 & Case report & 1 patient & Romiplostim treatment & 1 year & $\begin{array}{c}\text { Complete remission of } \\
\text { severe } \\
\text { thrombocytopenia }\end{array}$ & [85] \\
\hline 25 & Case report & 1 patient & Romiplostim treatment & NA & $\begin{array}{c}\text { Thrombocytopenia } \\
\text { evaluation during the } \\
\text { treatment }\end{array}$ & [76] \\
\hline 26 & Cohort study & $\begin{array}{c}18 \text { Korean IT } \\
\text { patients }\end{array}$ & Eltrombopag treatment & 4.5 years & $\begin{array}{l}\text { Optimal dose of } \\
\text { eltrombopag }\end{array}$ & [44] \\
\hline 27 & Retrospective study & $\begin{array}{c}18 \text { patients, } 5 \\
\text { splenectomised }\end{array}$ & Romiplostim treatment & NA & $\begin{array}{l}\text { Optimal response of } \\
\text { patients with platelets } \\
>20 \times 10^{9} / \mathrm{L} \text { at the } \\
\text { start of the treatment }\end{array}$ & [8] \\
\hline 28 & Prospective study & 6 patients & TRA treatment & NA & Platelet survival & [55] \\
\hline 29 & Case report & 1 patient & Romiplostim treatment & NA & Bone marrow fibrosis & [36] \\
\hline
\end{tabular}


FARMACIA, 2021, Vol. 69, 2

\begin{tabular}{|c|c|c|c|c|c|c|}
\hline No. & $\begin{array}{c}\text { Design } \\
\text { (as author defined it) }\end{array}$ & $\begin{array}{c}\text { Number of } \\
\text { patients }\end{array}$ & Intervention & Follow up & Aim of the study & Reference \\
\hline 30 & Retrospective study & $\begin{array}{l}200 \text { patients, } 361 \\
\text { (control) }\end{array}$ & TI treatment & $\mathrm{NA}$ & $\begin{array}{l}\text { Correlations between } \\
\text { polymorphism of beta } \\
1 \text { tubulin } \mathrm{R} 307 \mathrm{H} \text { and } \\
\text { efficacy of treatment }\end{array}$ & [11] \\
\hline 31 & Prospective study & $\begin{array}{c}299 \text { patients, } 33 \% \\
\text { with concomitant } \\
\text { medication, } 38 \% \\
\text { splenectomised }\end{array}$ & Eltrombopag treatment & 3 years & Safety and efficacy & [72] \\
\hline 32 & Prospective study & Cord culture cells & $\begin{array}{c}\text { High dose } \\
\text { Romiplostim treatment }\end{array}$ & NA & $\begin{array}{c}\text { Effect on } \\
\text { megakaryocytes }\end{array}$ & [27] \\
\hline 33 & Case series & 2 patients & TRA treatment & NA & $\begin{array}{c}\text { Cross resistance of } \\
\text { TRA }\end{array}$ & [28] \\
\hline 34 & Retrospective analyse & $\begin{array}{l}46 \text { patients, } 23 \\
\text { splenectomised }\end{array}$ & TRA treatment & NA & $\begin{array}{c}\text { Changing between } \\
\text { TRA }\end{array}$ & [43] \\
\hline 35 & Case study & 1 patient & \begin{tabular}{|c|} 
Romiplostim, \\
rituximab and \\
Vincristine \\
combination treatment
\end{tabular} & 74 days & $\begin{array}{c}\text { Acute severe IT with } \\
\text { bleeding }\end{array}$ & [59] \\
\hline 36 & Case study & 1 patient & TRA treatment & NA & $\begin{array}{l}\text { Cross efficacy of } \\
\text { romiplostim and } \\
\text { eltrombopag }\end{array}$ & [63] \\
\hline 37 & $\begin{array}{c}\text { Cohort retrospective } \\
\text { study }\end{array}$ & $\begin{array}{l}900 \text { patients, } 50 \% \\
\text { with splenectomies }\end{array}$ & TRA treatment & NA & $\begin{array}{l}\text { Cost - efficiency } \\
\text { report of rimiplostim } \\
\text { and eltrombopag }\end{array}$ & {$[50,51]$} \\
\hline 38 & Case study & 1 patient & $\begin{array}{c}\text { Pregnancy } \\
\text { Romiplostim treatment }\end{array}$ & 10 months & $\begin{array}{c}\text { Romiplostim } \\
\text { efficiency during } \\
\text { pregnancy }\end{array}$ & {$[62]$} \\
\hline 39 & Case-control study & $\begin{array}{c}62 \mathrm{TI} \text { and acute } \\
\text { leukaemia patients } \\
\text { (case group), } 4759 \\
\text { IT patients (control } \\
\text { group) }\end{array}$ & TRA treatment & NA & $\begin{array}{c}\text { Association between } \\
\text { Romiplostim and } \\
\text { acute leukaemia }\end{array}$ & [60] \\
\hline 40 & Case study & 1 patient & TRA treatment & 50 months & $\begin{array}{c}\text { Cross resistance of } \\
\text { TRA }\end{array}$ & [74] \\
\hline 41 & Case study & 1 patient & Romiplostim treatment & NA & Bone marrow fibrosis & [70] \\
\hline 42 & $\begin{array}{l}\text { Retrospective study } \\
\text { followed by } \\
\text { prospective study }\end{array}$ & $\begin{array}{l}66 \text { IT patients, } 50 \\
\text { lymphoma patients }\end{array}$ & TRA treatment & NA & Bone marrow fibrosis & [33] \\
\hline 43 & Case-control study & $\begin{array}{l}13 \text { IT patients TRA } \\
\text { treated, } 2 \text { IT } \\
\text { splenectomised, } 17 \\
\text { IT patients treated } \\
\text { with } \\
\text { immunoglobulins }\end{array}$ & TRA treatment & NA & $\begin{array}{c}\text { Effect of TRA on } \\
\text { plasma APRIL } \\
\text { (proliferation - } \\
\text { inducing ligand) } \\
\text { levels on IT patients }\end{array}$ & [4] \\
\hline 44 & Prospective study & 12 patients & $\begin{array}{l}\text { Eltrombopag and } \\
\text { dexamethasone } \\
\text { treatment }\end{array}$ & 12,5 months & $\begin{array}{l}\text { Treatment of new } \\
\text { diagnosed IT }\end{array}$ & [35] \\
\hline 45 & Case-control study & $\begin{array}{c}13 \text { IT patients, } 13 \\
\text { healthy individuals }\end{array}$ & TRA treatment & 2 weeks & $\begin{array}{c}\text { Effect of TRA on } \\
\text { platelet survival }\end{array}$ & [57] \\
\hline 46 & Case series & 2 patients & $\begin{array}{l}\text { Romiplostim and } \\
\text { corticosteroids } \\
\text { treatment }\end{array}$ & & $\begin{array}{l}\text { Efficacy of } \\
\text { combination }\end{array}$ & {$[52]$} \\
\hline 47 & Case report & 1 patient & $\begin{array}{l}\text { Eltrombopag and } \\
\text { cyclophosphamide in } \\
\text { refractory IT }\end{array}$ & 12 months & Efficacy and safety & [5] \\
\hline 48 & Retrospective analyse & 41 patients & Romiplostim treatment & NA & Efficacy and safety & [15] \\
\hline 49 & $\begin{array}{c}\text { Multicentric } \\
\text { retrospective study }\end{array}$ & 15 patients & Romiplostim treatment & 10 months & Efficacy and safety & [71] \\
\hline 50 & $\begin{array}{c}\text { Multicentric } \\
\text { retrospective study }\end{array}$ & $\begin{array}{l}14 \text { refractory } \\
\text { patients }\end{array}$ & TRA treatment & 15 months & Efficacy & [45] \\
\hline
\end{tabular}


FARMACIA, 2021, Vol. 69, 2

\begin{tabular}{|c|c|c|c|c|c|c|}
\hline No. & \begin{tabular}{|c|} 
Design \\
(as author defined it) \\
\end{tabular} & $\begin{array}{c}\text { Number of } \\
\text { patients }\end{array}$ & Intervention & Follow up & Aim of the study & Reference \\
\hline 51 & $\begin{array}{c}\text { Multicentric } \\
\text { retrospective study }\end{array}$ & 743 & Avatrombopag & 6 months & Efficacy and safety & [83] \\
\hline 52 & $\begin{array}{c}\text { Prospective } \\
\text { multicentric study }\end{array}$ & 64 & Avatrombopag & 1 month & Efficacy and safety & [16] \\
\hline 53 & $\begin{array}{c}\text { Prospective } \\
\text { multicentric study }\end{array}$ & 49 & Avatrombopag & 6 months & Efficacy and safety & [39] \\
\hline 54 & $\begin{array}{c}\text { Prospective } \\
\text { multicentric study }\end{array}$ & 296 & Avatrombopag & 3 weeks & Efficacy & [69] \\
\hline 55 & $\begin{array}{c}\text { Prospective } \\
\text { multicentric study }\end{array}$ & 204 & Avatrombopag & 1 week & Efficacy & [80] \\
\hline 56 & Retrospective analysis & 615 & $\begin{array}{l}\text { Avatrombopag, } \\
\text { eltrombopag, } \\
\text { romiplostim }\end{array}$ & 6 months & Efficacy and safety & [21] \\
\hline 57 & Theoretical analysis & Not applicable & $\begin{array}{l}\text { Avatrombopag, } \\
\text { eltrombopag, } \\
\text { romiplostim }\end{array}$ & $\begin{array}{c}\text { Not } \\
\text { applicable }\end{array}$ & Efficacy and safety & [3] \\
\hline 58 & Theoretical analysis & Not applicable & Avatrombopag & $\begin{array}{c}\text { Not } \\
\text { applicable }\end{array}$ & Efficacy and safety & [52] \\
\hline 59 & $\begin{array}{c}\text { Prospective } \\
\text { randomized study }\end{array}$ & 49 & Avatrombopag & 6 months & Efficacy and safety & [8] \\
\hline
\end{tabular}

Current evidence of the efficacy and safety of TRA According to our literature search, the efficacy of treatment is the subject of 52 studies, being evaluated by obtaining and maintaining remission (high platelet counts) after treatment completion [2, 3, 16, 17, 29, $32,39,61,55,57,71,77,79,84]$, decrease in the number of haemorrhagic episodes $[16,31,39,59,60$, $68,77]$, immunomodulatory activity $[4,9]$, avoidance of splenectomy [40, 49], reduction or withdraw of concomitant medication $[16,56]$. It was also intended to correlate certain factors with the efficacy of the treatment: thrombopoietin level [2, 3, 21, 54], tuberculin R307H nucleotide polymorphism [11], thrombocyte count above $20000 / \mu \mathrm{L}$ at the initiation of treatment [8]. In all the studies included in this review, the administered dosages were the standard ones for all three drugs $[2,7,16,20,22,23,26,29,39,45,58$, $82,83]$.

A study [42] and a series of case presentations [28, $63,74,75]$ focusing on the lack of cross-resistance between eltrombopag and romiplostim, showed that a drug is effective despite the inefficiency of the other. Khellaf et al. reported that $80 \%$ of patients who did not respond to eltrombopag, responded to romiplostim, respectively $46 \%$ who did not respond to romiplostim, responded to eltrombopag [43]. Patients refractory to multiple previous treatments and then to a TRA were responsive to treatment with the other agent [28, 63, 74, 75].

Obtaining and maintaining remission after treatment are an important criterion for evaluating the effectiveness of the treatment. Most of studies reported the increase in platelet counts, obtaining the remission of the disease $[2,4,5,14-17,32,37-39,46,49,53,71,72$, $76,84]$. In some cases, thrombocytopenia reoccurred when a medication was interrupted. Several studies reported maintaining remission for $29 \%-60 \%$ of patients treated with TRA, refractory to multiple treatment lines. Data reporting was performed over 4.5 to 6 years after discontinuation. The recommendation of most authors is that once the therapeutic goal is reached at an effective minimum dose, to stop the therapy aiming to maintain remission in the absence of treatment [8, 14, 17, 32, 37, 42, 84].

The primary objective of the treatment of immune thrombocytopenia is to decrease the number and intensity of haemorrhagic episodes, for this reason this parameter is the strongest evidence of TRA treatment efficacy. A large study of 299 patients diagnosed with primary IT, at least 6 months refractory to 2 - 3 treatment lines, treated with eltrombopag, demonstrated a decrease in haemorrhagic events after treatment. $38 \%$ of patients experienced severe bleeding events (3 - 4 degree) before starting the treatment. After TRA, half of the patients had no bleeding and $13 \%$ had only moderate bleeding ( $1-2$ degree). The treatment lasted for an average of 25 weeks and the follow-up period was 3 years [71]. These results are also confirmed by other studies with eltrombopag $[5,44,68]$.

Similar results in the reduction of haemorrhagic episodes are also reported with romiplostim $[15,31$, 53, 59, 71, 84]. One study evaluated 125 patients treated with romiplostim, compared to placebo. After 6 months of follow-up, in the placebo group, $24.4 \%$ had 4 or more severe haemorrhagic events than in the romiplostim group. $15.5 \%$ of the patients treated with romiplostim experienced a small number of mild haemorrhagic episodes [31]. Bussel et al. in a trial based on 64 avatrombopag treated patients proved a decrease in the proportion of subjects with bleeding by week 14 of treatment [16]. 
Many studies have tracked the effectiveness of TRA administered together with concomitant medication. The results were positive, treatment efficacy has been shown in addition to increase platelet counts, decreased bleeding episodes and dose reduction or interruption of concomitant medication that was represented by corticotherapy [6, 35, 56, 72], cyclophosphamide, danazol [5], intravenous immunoglobulin [68], rituximab and vincristine [59]. A randomised trial based on 64 patients treated with avatrombopag, included a subgroup of 23 subjects treated with steroids as concomitant medication. Thirteen of them had a $\geq 50 \%$ reduction in steroid dose and 8 permanently discontinued concomitant steroid medication after four weeks avatrombopag treatment [16].

Other studies that have demonstrated the efficacy of TRA, highlighted the following issues: efficacy of eltrombopag use before invasive non-dental procedures associated with bleeding risk in patients with chronic immune thrombocytopenia [77], treatment efficacy in a case of immune thrombocytopenia in a patient with immunodeficiency and infections, the optimal cost-effectiveness ratio of Romiplostim compared to other drugs [50, 51], TRA-regulating effect on Tlymphocytes (possibly mediated via platelet/megakaryocyte-mediated TGF- $\beta 1$ ), pathogenetic cells in immune thrombocytopenia $[4,9,10]$.

Elevated levels of endogenous thrombopoietin were correlated with the absence of response to TRA ( $\mathrm{p}<$ 0.002) [54]. This data was infringed by Kuter et al., who demonstrated that correlation between endogenous thrombopoietin and absence of response to TRA was not statistically significant in a study based on Romiplostim [47]. The impact of endogenous thrombopoietin level and platelet response to avatrombopag has not been studied [21].

As in the case of other drugs [66], TRA have differences in pharmacokinetics for different ethnicities. Because of that, treatment of Asian patients starts at lower doses. Two studies evaluated the efficacy of eltrombopag on groups of Japanese and Korean patients $[44,81]$. The response rate for the Japanese population was between $47.8 \%$ and $69.6 \%$ and the Korean population was $67 \%$, with patients with refractory primary thrombocytopenia treated on multiple lines [81, 44]. At the end of treatment all Japanese patients fall back within two weeks [81] and $83.3 \%$ of Korean patients [44].

The safety of treatment was the main subject of 22 studies. Most studies reported the development of bone marrow fibrosis after TRA [12, 14, 33, 44, 48, $60,70]$, but the most severe adverse effects were thrombosis [14, 16, 31, 72, 82] or thrombocytopenia that occurred after discontinuation $[49,69,81]$. The incidence of adverse reactions reported in a study of eltrombopag (299 patients) was $43 \%$ of which only $11 \%$ had severe adverse effects [72]. Two important trials centred on avatrombopag showed no significant difference in severe adverse effects in patients treated with avatrombopag versus placebo. These studies have demonstrated a slight difference for adverse effects after the administration of avatrombopag compared to placebo $[16,39]$

It's difficult to demonstrate the occurrence of bone marrow fibrosis after TRA treatment because in immune thrombocytopenia a bone marrow biopsy is not routinely performed. This is an examination of choice for evidence of fibrosis. However, the fibrosis after Romiplostim treatment is low degree (2 degree of 4 ). Medullary fibrosis has no clinical consequence and decreases when the treatment is stopped $[12,33]$. A prospective study on a group of 142 patients reported 8 cases of bone fibrosis, but bone marrow biopsy was not routinely performed [14]. In another study of 217 patients suffering IT, TRA treated, for 11 there were performed bone marrow biopsies and 10 cases were positive for bone marrow fibrosis, which decreased after stopping the treatment [48]. Bone marrow fibrosis was not reported in the case of avatrombopag.

Thrombocytopenia was considered by most authors as the most severe adverse effect of TRA treatment and occurred approximately 2 weeks after discontinuation of the treatment. Thrombocytopenia correlated with a severe haemorrhagic syndrome. The incidence of thrombocytopenia was $1.4 \%$ in one study done based on a group of 291 patients [15, 21, 39, 49, 81].

The appearance of deep vein thrombosis was analysed on a group of 299 patients and occurred in $2 \%$ of the patients that had other thrombogenic risk factor [72]. Another study in a group of 142 patients with chronic immune thrombocytopenia treated with Romiplostim, reported 5\% post-treatment thrombosis [14], while other studies [4, 31, 49] did not report thrombosis differences between TRA treatment and placebo, or did not record the appearance of thrombosis. Avatrombopag was incriminated in 5 thrombotic events occurred in a group of 64 patients, but there were not severe adverse events [16].

The only study that demonstrated a statistically significant association between TRA and the occurrence of acute myeloblastic leukemia (AML) was conducted by Oshima in Japan [59]. Of the 4821 patients with primary immune thrombocytopenia, 594 patients were treated with eltrombopag and 62 developed AML, respectively 3102 were treated with Romiplostim and 54 developed AML. TRA use, male gender and age between 60 to 69 years were associated with AML. Given the multifactorial determinism of AML, there can be no clear conclusion that the treatment with TRA causes AML [59]. One avatrombopag treated patient developed leucocytosis and after a short period of time was diagnosed with myelodysplastic syndrome which transformed in acute myeloid leukaemia. It's difficult to prove a causality between avatrombopag and leukaemia development [16]. 
Other side effects reported by different studies for all the three drugs were low-grade reactions such as rhinopharyngitis [72], hepatocitolysis, cholestasis $[44,81]$, headache $[15,16,39,42,49,52]$, fatigue $[16,42,49]$ or severe side effects like cataract in $5 \%$ of patients which were also treated with corticosteroids and the exact cause of cataract was not established [72]. Other severe side effects reported for avatrombopag were vomiting and headache [21, 39]. We compared the results of our systematic review with those of other published systematic reviews that were not included in our study [20, 22, 26, 73, 83, 67]. Most conclusions were comparable. Discordance may appear regarding the used parameters for monitoring the efficacy of the treatment, these parameters being different from one study to another (increased posttreatment platelet counts, reduction of bleeding episodes, avoidance of splenectomy, reduction or discontinuation of concomitant medication, etc.).

Bleeding events are a common complication of the disease and their evaluation is the best method to assess the efficacy of immune thrombocytopenia treatment as recommended by the European Medicines Agency [64]. In our review, we found a reduction in haemorrhagic events, on average about $50 \%$ of patients had not experienced haemorrhages following TRA administration, and in case of $10-20 \%$ of patients, severity of bleeding decreased, from $3-4$ degree to 1 - 2 degree of bleeding [31, 59, 60, 68, 77]. These results are concordant to the other reviews published on the same topic [20, 22, 26, 67, 73, 83]. The efficacy and safety of romiplostim, eltrombopag and avatrombopag were comparable in all studies analysed. We have not identified primary studies to compare the efficacy of the three drugs across different groups of patients. Boyers et al. demonstrated greater efficacy of romiplostim over eltrombopag through an indirect study analysing other publications. After that, they noted an error in the previous analysis, the primary effect being different in studies with romiplostim (probability of achieving a durable platelet response) versus eltrombopag (the probability of achieving a platelet count of $\left.50-400 \times 10^{9} / \mathrm{L}\right)$. There were also differences between the design of the studies and the definitions of the response to treatment. The authors reanalysed the data by correcting the errors of the research methodology by applying other statistical methods. The new results did not show a statistically significant difference between the efficacies of the two treatments [13].

The limits of this review of literature are mainly represented by the small groups of patients in most studies. We have also included trials of hundreds of patients $[11,14,31,37,46,49,54,56,69,72,77]$. TRA treatment is a new approved one, it is not a $1^{\text {st }}$ line treatment, it is reserved for refractory cases, so the number of patients undergoing therapy with these agents is not large. Last but not least, treatment has not been studied for long enough, evidence of longterm safety is still limited.

\section{Conclusions}

Thrombopoietin receptor analogues (romiplostim, eltrombopag and avatrombopag) are a new line therapy recommended for the second line for immune thrombocytopenic purpura. These drugs have proven a good efficacy and tolerance; the safety results so far are promising.

The efficacy of the treatment was evaluated in the 59 studies reviewed by obtaining and maintaining post-treatment remission, decreasing the number and intensity of bleeding episodes and avoiding splenectomy. The main adverse events reported were the appearance of low degree and reversible post-treatment bone marrow fibrosis, the most severe adverse effects being thrombosis or thrombocytopenia occurred after discontinuation of treatment.

Studies still need to be made to assess the safety of long-term treatment as well as to find factors associated with sustained remission after discontinuation of treatment. Perhaps in the future new molecules could correct the downs of the current medication.

\section{Conflict of interest}

The authors declare no conflict of interest.

\section{References}

1. Altomare I, Wasser J, Pullarkat V, Bleeding and mortality outcomes in ITP clinical trials: a review of thrombopoietin mimetics data. Am J Hematol., 2012; 87(10): 984-987.

2. Al-Samkari H, Kuter DJ, Optimal use of thrombopoietin receptor agonists in immune thrombocytopenia. Ther Adv Hematol., 2019; 10: 1-13.

3. Al-Samkari H, Kuter DJ, Relative potency of the thrombopoietin receptor agonists eltrombopag, avatrombopag and romiplostim in a patient with chronic immune thrombocytopenia. Br J Haematol., 2018; 183(2): 168

4. Álvarez RMT, Fernández BI, Arias-Salgado EG, de Paz R, Jiménez YV, Martín Salces M, Butta, NV, Effect of thrombopoietin-receptor agonists on a proliferation-inducing ligand (APRIL) plasma levels in patients with immune thrombocytopaenia. $\mathrm{Br} J$ Clin Pharmacol., 2014; 78(3): 674-676.

5. Anwer F, Yun S, Nair A, Ahmad Y, Krishnadashan R, Deeg HJ, Severe refractory immune thrombocytopenia successfully treated with high-dose pulse cyclophosphamide and eltrombopag. Case Rep Hematol., 2015; 2015: 58345: $1-4$.

6. Aoki T, Harada Y, Matsubara E, Suzuki T, Oyama T, Kasai M, Uchida T, Ogura M, Thrombopoietin receptor agonists in refractory immune thrombocytopenia: differential responses to eltrombopag and romiplostim: a case report and possible explanations. J Clin Pharm Ther., 2012; 37(6): 729-732.

7. Arnold DM, Patriquin C, Toltl LJ, Nazi I, Smith J, Kelton J, Diseases of Platelet number: immune 
thrombocitopenia, neonatal alloimmune thrombocytopenia and posttransfusional purpura. In: Hematology Basic Principles and Practice $6^{\text {th }}$ ed, Hoffman R, ed. Elsevier, Philadelphia, 2013; 1183-1194.

8. Baldini S, Rigacci L, Carrai V, Alterini R, Fjerza R, Bosi A, Patients with $\geq 20 \times 109 / \mathrm{L}$ platelets at baseline may have a prompt response to romiplostim during the early phase of treatment: an Italian single-institution experience. Mediterr J Hematol Infect Dis., 2012; 4(1): e2012044: 1-5.

9. Bao W, Bussel JB, Heck S, He W, Karpoff M, Boulad N, Yazdanbakhsh K, Improved regulatory T-cell activity in patients with chronic immune thrombocytopenia treated with thrombopoietic agents. Blood, 2010; 116(22): 4639-4645.

10. Barsam SJ, Psaila B, Forestier M, Page LK, Sloane PA, Geyer JT, Villarica GO, Ruisi MM, Gernsheimer TB, Beer JH, Bussel JB, Platelet production and platelet destruction: assessing mechanisms of treatment effect in immune thrombocytopenia. Blood, 2011; 117(21): 5723-5732.

11. Basciano PA, Bussel J, Hafeez Z, Christos PJ, Giannakakou P, The beta 1 tubulin $\mathrm{R} 307 \mathrm{H}$ single nucleotide polymorphism is associated with treatment failures in immune thrombocytopenia (ITP). $\mathrm{Br} \mathrm{J}$ Haematol., 2013; 160(2): 237-243.

12. Boiocchi L, Orazi A, Ghanima W, Arabadjief M, Bussel JB, Geyer JT, Thrombopoietin receptor agonist therapy in primary immune thrombocytopenia is associated with bone marrow hypercellularity and mild reticulin fibrosis but not other stromal abnormalities. Mod Pathol., 2012; 25(1): 65-74.

13. Boyers D, Jia X, Crowther M, Jenkinson D, Fraser C, Mowatt G, Eltrombopag for the treatment of chronic idiopathic (immune) thrombocytopenic purpura (ITP). Health Technol Assess., 2011; 15 (Suppl 1): 23-32.

14. Bussel JB, Kuter DJ, Pullarkat V, Lyons RM, Guo M, Nichol JL, Safety and efficacy of long-term treatment with romiplostim in thrombocytopenic patients with chronic ITP. Blood, 2009; 113(10): 2161-2171.

15. Bussel JB, Kuter DJ, George JN, McMillan R, Aledort LM, Conklin GT, Lichtin AE, Lyons RM, Nieva J, Wasser JS, Wiznitzer I, Kelly R, Chen CF, Nichol JL, AMG 531, a Thrombopoiesis-Stimulating Protein, for Chronic ITP. N Engl J Med., 2006; 355(16): 1672-1681.

16. Bussel JB, Kuter DJ, Aledort LM, Kessler CM, Cuker A, Pendergrass KB, Tang S, McIntosh J, A randomized trial of avatrombopag, an investigational thrombopoietin- receptor agonist, in persistent and chronic immune thrombocytopenia. Blood., 2014; 123(25): 3887-3894.

17. Carpenedo M, Cantoni S, Coccini V, Fedele M, Morra E, Pogliani EM, Feasibility of Romiplostim Discontinuation in Adult Thrombopoietin-Receptor Agonist Responsive Patients with Primary Immune Thrombocytopenia: An Observational Retrospective Report in Real Life Clinical Practice. Hematol Rep., 2015; 7(1): 2573: 1-4.

18. Cines DB, Bussel JB, Liebman HA, Luning Prak ET, The ITP syndrome: pathogenic and clinical diversity. Blood, 2009; 113(26): 6511-6521.
19. Cines DB, McMillan R, Pathogenesis of chronic immune thrombocytopenic purpura. Curr Opin Hematol., 2007; 14(5): 511-514.

20. Cines DB, Wasser J, Rodeghiero F, Chong BH, Steurer M, Provan D, Lyons R, Garcia-Chavez J, Carpenter N, Wang X, Eisen M, Safety and efficacy of romiplostim in splenectomized and nonsplenectomized patients with primary immune thrombocytopenia. Haematologica, 2017, 102(8): 1342-1351.

21. Cheloff ZA, Samkari-Al H, Avatrombopag for the treatment of immune thrombocytopenia and thrombocytopenia of chronic liver disease. J Blood Med., 2019; 10: 313-321.

22. Cheng G, Eltrombopag, a thrombopoietin- receptor agonist in the treatment of adult chronic immune thrombocytopenia: a review of the efficacy and safety profile. Ther Adv Hematol., 2012; 3(3): 155-164.

23. Cheng G, Saleh MN, Marcher C, Vasey S, Mayer B, Aivado M, Arning M, Stone NL, Bussel JB, Eltrombopag for management of chronic immune thrombocytopenia (RAISE): a 6-month, randomised, phase 3 study. Lancet, 2011; 377(9763): 393-402.

24. Chertes A, Crisan O, Stadards for good pharmacy practice - a comparative analysis. Farmacia, 2019; 67(3): 545-550.

25. Connell TN, Berliner N, Fostamatinib for the treatment of chronic immune thrombocytopenia. Blood, 2019; 113(19): 2027-2030.

26. Cooper N, Terrinoni I, Newland A, The efficacy and safety of romiplostim in adult patients with chronic immune thrombocytopenia. Ther Adv Hematol., 2012; 3(5): 291-298.

27. Currao M, Balduini CL, Balduini A, High Doses of Romiplostim Induce Proliferation and Reduce Proplatelet Formation by Human Megakaryocytes. PLoS One, 2013; 8(1): e54723: 1-6.

28. D'Arena G, Guariglia R, Mansueto G, Martorelli MC, Pietrantuono G, Villani O, Lerose R, Musto P, No cross-resistance after sequential use of romiplostim and eltrombopag in chronic immune thrombocytopenic purpura. Blood, 2013; 121(7): 1240-1242.

29. Fukushima-Shintani M, Suzuki K, Iwatsuki Y, Abe M, Sugasawa K, Hirayama F, Kawasaki T, Nakahata T, AKR-501 (YM477) a novel orally-active thrombopoietin receptor agonist. Eur J Haematol., 2009; 82(4): 247-254.

30. George JN, Sequence of treatments for adults with primary immune thrombocytopenia. Am J Hematol., 2012; 87(Suppl1): 12-15.

31. Gernsheimer TB, George JN, Aledort LM, Tarantino MD, Sunkara U, Matthew Guo D, Nichol JL, Evaluation of bleeding and thrombotic events during long-term use of romiplostim in patients with chronic immune thrombocytopenia (ITP): Bleeding and thrombotic events with romiplostim. J Thromb Haemost., 2010; 8(6): 1372-1382.

32. Ghadaki B, Nazi I, Kelton JG, Arnold DM, Sustained remissions of immune thrombocytopenia associated with the use of thrombopoietin receptor agonists. Transfusion., 2013; 53(11): 2807-2812.

33. Ghanima W, Geyer JT, Lee CS, Boiocchi L, Orazi A, Bussel JB, Bone marrow fibrosis in 66 patients with immune thrombocytopenia treated with thrombopoietin- 
receptor agonists: a single-center, long-term followup. Haematologica., 2014; 99(5): 937-944.

34. Ghanima W, Godeau B, Cines DB, Bussel JB, How I treat immune thrombocytopenia: the choice between splenectomy or a medical therapy as a second-line treatment. Blood, 2012; 120(5): 960-969.

35. Gómez-Almaguer D, Herrera-Rojas MA, Jaime-Pérez JC, León AGD, Cantú-Rodríguez OG, GutiérrezAguirre CH, Tarín-Arzaga L, Hernández-Reyes J, Ruiz-Arguelles GJ, Eltrombopag and high-dose dexamethasone as frontline treatment of newly diagnosed immune thrombocytopenia in adults. Blood, 2014; 123(25): 3906-3908.

36. Gonzalez MF, Freeman JK, Myelofibrosis Associated with Romiplostim Treatment in a Patient with Immune Thrombocytopenia. Case Rep Hematol., 2012; 2012: 318597: 1-4.

37. González-López TJ, Pascual C, Álvarez-Román MT, Fernández-Fuertes F, Sánchez-González B, Caparrós I, Jarque I, Mingot-Castellano ME, Hernández-Rivas JA, Martín-Salces M, Solán L, Beneit P, Jiménez R, Bernat S, Andrade MM, Cortés M, Cortti MJ, PérezCrespo S, Gómez-Núñez M, Olivera PE, Pérez-Rus G, Martínez-Robles V, Alonso R, Fernández-Rodríguez A, Arratibel MC, Perera M., Fernández-Miñano C, Fuertes-Palacio MA, Vázquez-Paganini JA, GutierrezJomarrón I, Valcarce I, de Cabo E, Sainz A, Fisac R, Aguilar C, Paz Martínez-Badas M, Peñarrubia MJ, Calbacho M, de Cos C, González-Silva M, Coria E, Alonso A, Casaus A, Luaña A, Galán P, FernándezCanal C, Garcia-Frade J, González-Porras JR, Successful discontinuation of eltrombopag after complete remission in patients with primary immune thrombocytopenia. Am J Hematol., 2015; 90(3): 40-43.

38. Jenkins JM, Williams D, Deng Y, Uhl J, Kitchen V, Collins D, Erickson-Miller CL, Phase 1 clinical study of eltrombopag, an oral, nonpeptide thrombopoietin receptor agonist. Blood, 2007; 109(11): 4739-4741.

39. Jurczak W, Chojnowski K, Mayer J, Krawczyk K, Jamieson BD, Tian W, Allen LF, Phase 3 randomised study of avatrombopag, a novel thrombopoietin receptor agonist for the treatment of chronic immune thrombocytopenia. Br J Haematol., 2018; 183(3): 479-490.

40. Khalafallah A, Rahman Z, Ogden K, Hannan T, Successful Treatment with Thrombopoietin Receptor Agonist in Avoiding Splenectomy for Patients with Chronic Refractory Immune Thrombocytopenia. Mediterr J Hematol Infect Dis., 2012; 4(1): 1-5.

41. Khan M, Mikhael J, A review of immune thrombocytopenic purpura: focus on the novel thrombopoietin agonists. J Blood Med., 2010; 1: 21-31.

42. Khellaf M, Michel M, Quittet P, Viallard JF, Alexis M, Roudot-Thoraval F, Cheze S, Durand JM, Lefrère F, Galicier L, Lambotte O, Panelatti G, Slama B, Damaj G, Sebahoun G, Gyan E, Delbrel X, Dhedin N, Royer B, Schleinitz N, Rossi JF, Mahévas M, Languille L, Bierling P, Godeau B, Romiplostim safety and efficacy for immune thrombocytopenia in clinical practice: 2 -year results of 72 adults in a romiplostim compassionate-use program. Blood, 2011; 118(16): 4338-4345

43. Khellaf M, Viallard JF, Hamidou M, Cheze S, RoudotThoraval F, Lefrere F, Fain O, Audia S, Abgrall JF,
Michot JM, Dauriac C, Lefort S, Gyan E, Niault M, Durand JM, Languille L, Boutboul D, Bierling P, Michel M, Godeau B, A retrospective pilot evaluation of switching thrombopoietic receptor-agonists in immune thrombocytopenia. Haematologica, 2013; 98(6): 881-887.

44. Kim YK, Lee SS, Jeong SH, Ahn JS, Yang DH, Lee JJ, Kim HJ, Efficacy and safety of eltrombopag in adult refractory immune thrombocytopenia. Blood Res., 2015; 50(1): 19-25.

45. Kuter DJ, Bussel JB, Lyons RM, Pullarkat V, Gernsheimer TB, Senecal FM, Aledort LM, Kessler CM, Sanz MA, Liebman HA, Slovick FT, de Wolf JT, Bourgeois E, Guthrie TH Jr., Newland A, Wasser JS, Hamburg SI, Grande C, Lefrère F, Lichtin AE, Tarantino MD, Terebelo HR, Viallard JF, Cuevas FJ, Go RS, Henry DH, Redner RL, Rice L, Schipperus MR, Guo DM, Nichol JL, Efficacy of romiplostim in patients with chronic immune thrombocytopenic purpura: a double-blind randomised controlled trial. Lancet., 2008; 371(9610): 395-403.

46. Kuter DJ, Mathias SD, Rummel M, Mandanas R, Giagounidis AA, Wang X, Health-related quality of life in nonsplenectomized immune thrombocytopenia patients receiving romiplostim or medical standard of care. Am J Hematol., 2012; 87(5): 558-561.

47. Kuter DJ, Meibohm A, Lopez A, TPO concentrations and response to romiplostim. Am J Hematol., 2014; 89(12): 1155-1156.

48. Kuter DJ, Mufti GJ, Bain BJ, Hasserjian RP, Davis W, Rutstein M, Evaluation of bone marrow reticulin formation in chronic immune thrombocytopenia patients treated with romiplostim. Blood, 2009; 114(18): 37483756.

49. Kuter DJ, Rummel M, Boccia R, Macik BG, Pabinger I, Selleslag D, Rodeghiero F, Chong BH, Wang X, Berger DP, Romiplostim or Standard of Care in Patients with Immune Thrombocytopenia. N Engl J Med., 2010; 363(20): 1889-1899.

50. Lee D, Thornton P, Hirst A, Kutikova L, Deuson R, Brereton N, Cost Effectiveness of Romiplostim for the Treatment of Chronic Immune Thrombocytopenia in Ireland. Appl Health Econ Health Policy, 2013; 11(5): 457-469.

51. Lee D, Thornton P, Hirst A, Kutikova L, Deuson R, Brereton N, Erratum to: Cost Effectiveness of Romiplostim for the Treatment of Chronic Immune Thrombocytopenia in Ireland. Appl Health Econ Health Policy, 2013; 11(6): 687.

52. Li C, Li X, Huang F, Yang J, Wu A, Wang L, Qin D, Zou W, Wu J, Efficacy and Safety of Avatrombopag in Patients with Thrombocytopenia: A Systematic Review and Meta-Analysis of Randomized Controlled Trials. Front Pharmacol., 2019; 26(10):829: 1-12.

53. Mahévas M, Gerfaud-Valentin M, Moulis G, Terriou L, Audia S, Guenin S, Le Guenno G, Salles G, Lambotte O, Limal N, Viallard JF, Cheze S0, Tomowiak C, Royer B, Neel A, Debouverie O, Hot A, Durieu I, Perlat A, Cliquennois M, Deteix C, Michel M, Godeau B, Characteristics, outcome, and response to therapy of multirefractory chronic immune thrombocytopenia. Blood, 2016; 128(12): 1625-1630.

54. Makar RS, Zhukov OS, Sahud MA, Kuter DJ, Thrombopoietin levels in patients with disorders of 
platelet production: Diagnostic potential and utility in predicting response to TPO Receptor agonists. Am J Hematol., 2013; 88(12): 1041-1044.

55. Meyer O, Herzig E, Salama A, Platelet Kinetics in Idiopathic Thrombocytopenic Purpura Patients Treated with Thrombopoietin Receptor Agonists. Transfus Med Hemother., 2012; 39(1): 5-8.

56. Michel M, te Boekhorst PAW, Janssens A, PabingerFasching I, Sanz MA, Nie K, Kreuzbauer G, Reduced corticosteroid use in adult patients with primary immune thrombocytopenia receiving romiplostim. Hematology, 2011; 16(5): 274-277.

57. Mitchell WB, Pinheiro MP, Boulad N, Kaplan D, Edison MN, Psaila B, Karpoff M, White MJ, Josefsson EC, Kile BT, Bussel JB, Effect of thrombopoietin receptor agonists on the apoptotic profile of platelets in patients with chronic immune thrombocytopenia. Am J Hematol., 2014; 89(12): 228-234.

58. Neunert C, Terrell DR, Arnold DM, American Society of Hematology 2019 guidelines for immune thrombocytopenia. Blood Adv., 2019; 3(23):3829-3866. Erratum for: Blood Adv., 2019; 3(23): 3829-3866.

59. Okazuka K, Masuko M, Matsuo Y, Miyakoshi S, Tanaka T, Kozakai T, Kobayashi H, Fuse K, Shibasaki Y, Moriyama M, Takizawa J, Fuse I, Toba K, Furukawa $\mathrm{T}$, Successful treatment of severe newly diagnosed immune thrombocytopenia involving an alveolar hemorrhage with combination therapy consisting of romiplostim, rituximab and vincristine. Intern Med., 2013; 52(11): 1239-1242.

60. Oshima Y, Yuji K, Tanimoto T, Hinomura Y, Tojo A, Association between acute myelogenous leukemia and thrombopoietin receptor agonists in patients with immune thrombocytopenia. Intern Med., 2013; 52(19): 2193-21201.

61. Palandri F, Polverelli N, Lifrieri F, Catani L, Giannini MB, Baccarani M, Vianelli N, Romiplostim as early treatment of immune thrombocytopenia with severe immunodeficiency. Hematol Rep., 2012; 4(2): 28-29.

62. Patil AS, Dotters-Katz SK, Metjian AD, James AH, Swamy G, Novel Use of a Thrombopoietin Mimetic for Chronic Immune Thrombocytopenic Purpura in Pregnancy. Obstet Gynecol., 2013; 122(202): 483-485.

63. Piccin A, Amaddii G, Natolino F, Billio A, Cortelazzo $\mathrm{S}$, Idiopathic thrombocytopenic purpura resistant to eltrombopag, but cured with romiplostim. Blood Transfus., 2014; 12(Suppl 1): 149-150.

64. Pignatti F, Flores B, Jonsson B, Platelet response as the basis for approval in chronic immune (idiopathic) thrombocytopenic purpura (ITP): a regulatory perspective. Am J Hematol., 2012; 87(10): 943-944.

65. Poordad F, Terrault AN, Alkhouri N, Tian W, Allen FL, Rabinovitz M, Avatrombopag, an Alternate Treatment Option to Reduce Platelet Transfusions in Patients with Thrombocytopenia and Chronic Liver DiseaseIntegrated Analyses of 2 Phase 3 Studies. Int J Hepatol.., 2020; 2020: 1-11.

66. Pop TR, Vesa SC, Trifa AP, Crișan S, Buzoianu AD, An Acenocumarol Dose Algorithm Based on a SouthEastern European Population. Eur J Clin Pharmacol., 2013, 69 (11): 1901-1907.

67. Provan D, Stasi R, Newland AC, Blanchette VS, Bolton-Maggs P, Bussel JB, Chong BH, Cines DB, Gernsheimer TB, Godeau B, Grainger J, Greer I,
Hunt BJ, Imbach PA, Lyons G, McMillan R, Sanz MA, Tarantino M, Watson S, Young J, Kuter DJ, International consensus report on the investigation and management of primary immune thrombocytopenia. Blood, 2010; 115(2): 168-186.

68. Psaila B, Bussel JB, Linden MD, Babula B, Li Y, Barnard MR, Tate C, Mathur K, Frelinger AL, In vivo effects of eltrombopag on platelet function in immune thrombocytopenia: no evidence of platelet activation. Blood, 2012; 119(17): 4066-4072.

69. Pullarkat VA, Gernsheimer TB, Wasser JS, Newland A, Guthrie THJr, de Wolf JTM, Stewart R, Berger D, Quantifying the reduction in immunoglobulin use over time in patients with chronic immune thrombocytopenic purpura receiving romiplostim (AMG 531). Am J Hematol., 2009; 84(8): 538-540.

70. Rashidi A, Roullet MR, Romiplostim-induced myelofibrosis. Blood, 2013; 122(12): 2001.

71. Roumier M, Terriou L, Hamidou M, Dossier A, Morin AS, Zarrouk V, Ebbo M, Moulis G, Galicier L, Audia S, Languille L, Gousseff M, Poutrel S, Michel M, Godeau B, Mahévas M, A Multicenter Study Evaluating the Safety of Romiplostim at Maximal Dosage for Emergency Bleeding Situations in Immune Thrombocytopenia, Blood, 2016; 128(22): 2541.

72. Saleh MN, Bussel JB, Cheng G, Meyer O, Bailey CK, Arning M, Safety and efficacy of eltrombopag for treatment of chronic immune thrombocytopenia: results of the long-term, open-label EXTEND study. Blood, 2013; 121(3): 537-545.

73. Sarpatwari A, Bennett D, Logie JW, Shukla A, Beach KJ, Newland AC, Sanderson S, Provan D, Thromboembolic events among adult patients with primary immune thrombocytopenia in the United Kingdom General Practice Research Database. Haematologica, 2010; 95(7): 1167-1675.

74. Sartori R, Candiotto L, Ruggeri M, Tagariello G, Immune thrombocytopenia successfully treated with eltrombopag following multiple therapies including romiplostim. Blood Transfus., 2014; 12(Suppl 1): 151152.

75. Scaramucci L, Giovannini M, Niscola P, Tendas A, Perrotti A, de Fabritiis P, Reciprocal absence of crossresistance between eltrombopag and romiplostim in two patients with refractory immune thrombocytopenic purpura. Blood Transfus., 2014; 12(4): 605-607.

76. Shinohara K, Kambara N, Highly fluctuating thrombocytopenia developing in a patient with immune thrombocytopenia (ITP) while administering romiplostim. Intern Med., 2012; 51(11): 1399-1401.

77. Shirley M, Avatrombopag: first global approval. Drugs., 2018; 78(11): 1163-1168.

78. Stoian A, Motataianu A, Barcutean L, Maier S, Bajko Z, Voidazan S, Farcas A, Balasa R. Understanding the mechanism of action intravenous immunoglobulins: a ten years experience in treating Guillain Barre syndrome. Farmacia, 2020; 68(3): 426-435.

79. Tarantino MD, Bakshi KK, Brainsky A, Hemostatic challenges in patients with chronic immune thrombocytopenia treated with eltrombopag. Platelets, 2014; 25(1): 55-61.

80. Terrault NA, Hassanei T, Howell CD, Joshi S, Lake J, Sher L, Vargas H, McIntosh J, Tang S, Jenkins TM, Phase II study of avatrombopag in thrombocytopenic 
patients with cirrhosis undergoing an elective procedure. J. Hepatol., 2014; 61: 1253-1259.

81. Terrault N, Chen YC, Izumi N, Kayali Z, Mitrut P, Tak WY, Allen LF, Hassanein T, Avatrombopag before procedures reduces need of platelet transfusion in patients with chronic liver disease and thrombocytopenia. Gastroenterology, 2018; 155: 705-718.

82. Tomiyama Y, Miyakawa Y, Okamoto S, Katsutani S, Kimura A, Okoshi Y, Ninomiya H, Kosugi H, Nomura S, Ozaki K, Ikeda Y, Hattori T, Katsura K, Kanakura Y, A lower starting dose of eltrombopag is efficacious in Japanese patients with previously treated chronic immune thrombocytopenia. J Thromb Haemost., 2012; 10(5): 799-806.

83. Treutiger P, Holmström L, Additional analyses from phase 3 study with Doptelet (avatrombopag) for the treatment of chronic immune thrombocytopenia provides evidence of long-term response rates. Swedish Orphan Biovitrum AB., 2019; 22: 1-2.

84. Vishnu P, Aboulafia DM, Long-term safety and efficacy of romiplostim for treatment of immune thrombocytopenia. J Blood Med., 2016; 7: 99-106.

85. Vlachaki E, Papageorgiou V, Klonizakis F, Spandonidou M, Chisan S, Vetsiou E, Ioannidou E, Total remission of severe immune thrombocytopenia after short term treatment with romiplostim. Hematol Rep., 2011; 3(3): $1-2$.

86. Wörmann B, Clinical Indications for Thrombopoietin and Thrombopoietin-Receptor Agonists. Transfus Med Hemother., 2013; 40(5): 319-325.

87. Zeng Y, Duan X, Xu J, Ni X, TPO receptor agonist for chronic idiopathic thrombocytopenic purpura. Cochrane Database Syst Rev., 2011; (7): 008235: 1-56. 